\title{
RUSSIAN LINGUISTICS
}

\author{
Thanks \\ Werner Lehfeldt for his Major Contributions
}

Published online: 16 August 2018

(C) Springer Nature B.V. 2018

Werner Lehfeldt informed the Russian Linguistics editors that he wished to resign from the editorial board. The editors deeply regret the loss of such an esteemed board member, but respectfully accept his decision.

Werner Lehfeldt has been a leading scholar in the field of Slavic Linguistics for many years internationally and Russian Linguistics is proud to have had such a globally renowned linguist as an editorial team member since 1983 . He started out at the journal working alongside L. Durovič and A. G. F. van Holk, from 1993 to 2006 he was the editor-in-chief, and worked in close collaboration with his coeditors R. Comtet and A. G. F. van Holk until 1998, and then, R. Comtet and J. Schaeken. From 2007 onwards he was a member of the editorial board. The high scientific quality of the articles, as well as the broad spectrum of topics and themes covered within them and the excellent worldwide reputation that Russian Linguistics has in specialist circles internationally, is intrinsically linked to Werner Lehfeldt and his work for the journal.

Werner Lehfeldt was able to build up the journal's excellent reputation thanks to his superior skill at selecting which articles should be featured in a given volume of Russian Linguistics. The targeted precision with which he made these decisions, along with the help of his co-editors, was based on Werner Lehfeldt's infallible instinct for scientific exactness and innovative research achievements. This was coupled with great erudition, covering an impressively broad spectrum of slavistic-linguistic research literature.

At the same time, Werner Lehfeldt's own numerous research papers significantly enriched the content of the journal time and time again. His first article was published as early as 1980 and dealt with the topic Upravlenie, soglasovanie, primykanie v russkom jazyke in eighteen pages. The number of Werner Lehfeldt's reviews that have been published in Russian Linguistics over the years is vast and it is no coincidence that the first three (1980-1982) were dedicated to accentological texts by A. A. Zaliznjak, whom Werner Lehfeldt held in the highest esteem. A further eight reviews in the seventh volume of the journal alone bears witness to the importance and respect that he awarded this type of publication, thereby highlighting the significance of the authors reviewed (these were in 1982, amongst others, P. Garde, S. V. Bromlej, I. A. Mel'čuk and V. N. Bondarenko).

Werner Lehfeldt has made an invaluable contribution to Russian Linguistics and has played a crucial role in turning Russian Linguistics into a worldwide leading journal in its field. As editors, and in the name of all the contributing authors, as well as countless readers globally, we would like to offer Werner Lehfeldt our heartfelt thanks for this.

Roger Comtet Jos Schaeken Ulrich Schweier 